\title{
Uusien aikaorientaatioiden ongelma taidehistoriassa - anakronismi, kronotopia ja heterokronia
}

\section{Altti Kuusamo}

doi.org/10.23995/tht.112169

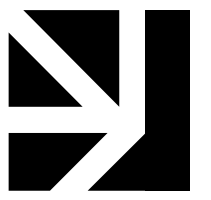

Tarkastelen artikkelissani taidehistoriallisessa tutkimuksessa viime aikoina yleistyneen anakronistisen asenteen eri näkökohtia. Pohdin, voiko anakronistinen asennoituminen murtaa ns. lineaarisen aikakäsityksen. Punnitsen myös anakronismin ajatusta kahden toisentyyppisen ajallisuuden käsitteen, kronotopian ja heterokronian valossa. Suhteeni anakronismin ideaan taidehistoriassa on kriittinen: analysoin tarkemmin, miten anakronismin ajatuksen keskeinen lähettiläs Georges Didi-Huberman soveltaa käsitettä. Liitän anakronismin idean aiempiin ajattoman taiteen puolestapuhujien ajatuksiin ja totean anakronismin uudeksi formalismin muodoksi.

Asiasanat: Anakronismi, kronotopia, heterokronia, Georges Didi-Huberman, Fra Angelico, formalismi, hermeneutiikka, Aby Warburg. 
Artikkelissani pohdin kriittisesti taidehistoriallisessa tutkimuksessa viime aikoina laajasti esiin noussutta kysymystä anakronismista. Tämä käsite on ilmaantunut haastamaan aiempia nykytutkimuksen käsityksiä taideteosten kronologisesta paikasta tilanteessa, jossa monitieteisyys yhä selkeämmin vaikuttaa tutkimusongelmiin ja menetelmiin. Tarkastelen anakronismin ja tutkimuksellisesti sangen uuden heterokronia-käsitteen ongelmallisia suhteita. Tämän teen unohtamatta näiden kahden käsitteen eräänlaista välijäsentä, kronotopiaa, sitä miten tietty paikka herättää tietyn ajan tai aikakauden. Pyrin myös tarkastelemaan näiden käsitteiden hermeneuttisia ulottuvuuksia.

Erityisesti kriittisen huomioni kohteeksi nousee anakronismin apologeetikon, Georges DidiHubermanin kirjoitukset, joiden lähtökohtana on ajatus taideteoksen ajallisesta epävakaisuudesta. Vastaavasti kohdistan kriittisen huomioni yhdysvaltalaisen modernismin teoreetikoiden, Michael Friedin ja Clement Greenbergin modernin taideteoksen ajattomuuden ideaan, jonka tulkitsen eräänlaiseksi esianakronismiksi. Kysyn: ovatko anakronismit aikamme uutta formalismia? Edelleen pohdin, kuinka anakronismikäsitykset muuttavat näkemystämme kuvataiteen traditiosta. Lopuksi ehdotan kronotopian ja heterokronian käsitteitä vaihtoehtoina anakronistiselle näkemykselle.

Anakronismin termi on peräisin kreikan kielen sanasta anakhronitsein - "asettaa väärään aikaan" tai "myöhästyä" tai "olla aikaa vastaan". Nykyisin on yleistynyt katsantokanta, jonka mukaan anakronismeiksi tulkitut ilmiöt taiteessa voivat murtaa taidehistorian "lineaarisen" aikakäsityksen. Kun artefakti on irrotettu lineaarisen ajan ankkuristaan ja ajelehtii vieraassa historiallisessa kontekstissa, se voidaan tulkita anakronistiseksi. ${ }^{1}$

$1 \quad$ Alexander Nagel \& Christopher Wood, Anachronic Renaissance (New York: Zone Books 2010), 13.
Jo Martin Heidegger pani teoksessaan Sein und Zeit (1927) merkille nykyaikaisen tavan ottaa huomioon oma ajallisuutemme humanistisessa tutkimuksessa: "Historiallisissa ihmistieteissä, tarve historialliseen aktuaalisuuteen, on vahvistunut perinteen, sen kuvauksen ja tradition myötä: kirjallisuushistoriasta on tulossa ongelmahistoriaa". Sama aktuaalisuuden tarve toteutui taidehistoriassa myöhemmin metoditietoisuuden kasvun kautta: nykyisyydessämme luodut tutkimusmenetelmät muokkaavat taiteen historian tulkintoja. Kysymys, miten tämä tapahtuu sekoittamatta taiteen historiaan uppoutuvaa kontekstuaalista tulkintatraditiota "ajattomuuteen", sivuaa monin tavoin anakronismin ongelmaa.

\section{Anakronismit kuvien "omana aikana"?}

Viime aikoina on katsottu, että nykytaiteen tekemät muunnelmat aiemmasta taiteesta auttavat ymmärtämään vanhaa taidetta syvällisemin. Mieke Bal on todennut, että "nykyajan barokkitaiteilijat", jotka tekevät muunnelmia Caravaggion teoksista, auttavat meitä ymmärtämään paremmin tämän maalauksia. ${ }^{3} \mathrm{Bal}$ on jopa todennut Caravaggiolta lainaamisen "muuttavan hänen teoksensa ikuisesti". ${ }^{4}$ Vastaavasti George Kubler katsoi aikanaan, että tietämys Auguste Rodinista muuttaa tulkintaamme Michelangelosta. ${ }^{5}$ Nämä kommentit saattavat pitää paikkansa joidenkin muotoratkaisujen suhteen ja saavat meidät huomaamaan jonkin yksityiskohdan, mutta syvempää ymmärryksen lisäystä Rodinin teokset tuskin tuovat Michelangelon veistoksiin.

2 Martin Heidegger, Sein und Zeit (Tübingen: Max Niemayer Verlag 1993), 10 (§ 3); vrt. Martin Heidegger, Oleminen ja aika (Tampere: Vastapaino, 2000), 30. Korostus AK.

3 Mieke Bal, Quoting Caravaggio. Contemporary Art, Preposterous History (Chicago \& London: The University of Chicago Press, 1999), 99.

4 Bal, Quoting Caravaggio, 1.

5 George Kubler, The Shape of time. Remarks on the History of Things (New Haven \& London: Yale University Press, 1962), 21. 
Tutkimukselle tällaiset visiot eivät lopultakaan anna mitään uutta. Kun tutkin Michelangelon melankolian tiettyä, tarkasti rajattua ongelmakenttää, ${ }^{6}$ Rodin olisi ollut vain häiritsevä tekijä. Mieke Bal onkin antanut nimen "nurinkurinen taidehistoria (preposterous art history)" asenteelle, joka kääntää kronologisesti myöhemmän kronologisesti aiemman edelle. Kyse on silloin historian tekemisestä nykypäivän teosten avulla. Balin mukaan se voidaan nähdä eräänlaisena "past today" -askarteluna.

Kuvien anakronistisessa tulkinnassa on oikeastaan neljä hyvin erilaista näkökohtaa: ensiksikin oletetaan, että kuvilla on omaa anakronistista voimaa murtautua kuvahistoriassa itsenäisesti läpi aikakausien. Tämä on Didi-Hubermanin oletus Aby Warburgin menetelmästä. ${ }^{8}$ Toiseksi meidän aikamme metodologiset käsitykset vaikuttavat kuvien historian tulkintoihin siinä määrin, että kuvien historia altistuu niille ja muuntuu täydellisesti tämän hetken tulkinnoissa. Kolmanneksi jokin nykyajan taideteos vaikuttaa tapaamme nähdä ensimmäinen oletus - se, että jokin kuva, esimerkiksi Victoria-hahmo, raivaa itsenäisesti tietään aikakaudesta toiseen - pelkästään historiallisen kuvan oman ominaisuuden voittokulkuna! Mieke Balin voi katsoa edustavan toista näistä näkökohdista (ks. viitteet 29-30). Kolmatta näkökulmaa voisi pitää DidiHubermanin käsitysten lähtökohtana, jota näkökohtaa tulee valaisemaan jatkossa esiin ottamani Fra Angelico -esimerkki.

Neljäs näkökulma liittyy kuvien kontekstialttiuteen: Aby Warburgin seuraaja Fritz Saxl toteaa teoksessaan $A$ Heritage of Images hellenistisen antiikin siivekkään Victoria-hahmon kuvallisen voiman niin suureksi, että se muutti pyhien tekstien tulkinnan - ja siten kristillinen enkeli peri

$6 \quad$ Altti Kuusamo, "Michelangelo ja melankolian vieteri," Synteesi nro 4 (2006): 25-31.

7 Bal, Quoting Caravaggio, 6-7.

8 Georges Didi-Huberman, L'image survivante, Histoire de d'art et temps des fantomes selon Aby Warburg (Paris: Les Éditions de Minuit, 2002), 82-83, 87 et passim. siipensä roomalaisen antiikin reliefeistä. Kuva voima liittyy tässä yhteydessä Victoria-hahmon voitto-funktion siirtymiseen. Oliko Saxlin olettamus anakronistinen? Saxlin omasta mielestä ei ollut. ${ }^{9}$

Didi-Hubermanin anakronia-teesin lähtökohta on Fra Angelicon erään San Marcon luostarissa olevan Sacra Conversazione -maalauksen alalaatat, jotka kuvaavat marmorointia (1438-50; San Marcon luostarin itäinen korridori, Firenze). Hän katsoo, ettei Michael Baxandallin lähtökohta Fra Angelicon maalausten kontekstoimiseksi ole onnistunut. Baxandallin pyrkimys selittää maalauksia humanisti Christoforo Landinon teorioiden avulla ei Didi-Hubermanin mukaan toimi heitä erottavan ajallisen etäisyyden (Fra Angelico - Landino) vuoksi. Didi-Hubermanin mukaan Zeitgeistin "ideaali koherenssi" ei voi selittää "maalattua pintaa" kompleksisena, "epäpuhtaan temporaalisuuden" objektina. ${ }^{10}$ Vastavetona Baxandallin erheeseen hän katsoo, että kuva on ajan suhteen erittäin ylideterminoitunut. Anakronismi on tässä tapauksessa "suvereenia" ja eukroniaa harrastava tutkija on siten tuomittu olemaan ymmärtämättä "kuvallista aktia". ${ }^{11}$

Didi-Hubermanin tekstissä Fra Angelicon marmoroinnin täplikäs kuvio saa perustelunsa Jackson Pollockin maalausten kautta. ${ }^{12}$ Hän näkee täplitetyn maalauksen itseriittoisena ja aikaan kytkettyjä selityksiä vastustavana. Objekti (pinta) alkaa elää omaa elämäänsä läpi erilaisten historiallisten kontekstien. Kuva aivan kuin itse tulkitsee itsensä. Maalauksen itseriittoisuus nähdään (lue: kontekstoidaan) Pollockin teosten kautta

9 Fritz Saxl, $A$ Heritage of Images (Harmondsworth: Penguin Books, 1970), 13-14.

10 Georges Didi-Huberman, "Before the image, Before Time: The Sovereignty of Anachronism," teoksessa Compelling Visuality, toim. Claire Farago \& Robert Zwijnenberg (Minneapolis \& London: University of Minnesota Press, 2003), 35-38.

11 Didi-Huberman, "Before the image, before Time," 39-41.

12 Ibid.

\section{TaHiTi 2/2021 $\mathbf{D}$}


- tavalla, joka ei tunnu kontekstoinnilta - koska viitataan vain teoksiin! Tässä on huomaamaton, mutta hyvin suuri ristiriita, ellei paradoksi. Kun maalaukset puhdistetaan hetkeksi konteksteistaan, ja ne irtoavat ympäröivästä historiastaan myyttisen nykytaiteen "taiteellisuuden" mallin mukaan - ja kykenevät siten lopulta piilottamaan kontekstinsa, tekemään kontekstin (nykytaide) ei-kontekstin näköiseksi!

Marmorointeja oli Fra Angelicon aikaan runsaasti. Se oli halpaa pintaa marmoriin nähden. Didi-Huberman kuitenkin näkee tämän pinnan itseriittoisena modernina "taiteena" - teospintana, joka synnyttää oman historiattoman metafysiikkansa. Useassa yhteydessä Didi-Huberman korostaa sitä, että kuvat ovat kompleksisia, avoimia ja disorientoivia: "Kuvien suvereenisuus anakronisoi läsnä olevaa nykyhetkeä ja on väkivaltaisessa suhteessa 'ajan henkeen"' ${ }^{13}$ Teos ikään kuin kykenee karistamaan aikasidonnaisuuden ja omat kontekstinsa ja lopulta lähestyy modernia taidetta tulemalla vertailukelpoiseksi sen kanssa! Näin kuvan historiallinen toiseus samalla katoaa. Ongelma myös on: miten kuvan "suora tutkiminen" on mahdollista? Tuleeko se mahdolliseksi juuri sen kautta, että kuva irrotetaan historiallisista konteksteistaan "ajattomaksi" tämänpäiväisyydeksi? Cesare Segren termein kysymys on ehkä siitä, että kuvan "suora tutkiminen" tarjoaa eräänlaisen "toisen temporaalisuuden". ${ }^{14}$ Kuvan suoraa tutkimista on kuitenkin tehtävä tietyillä kontekstuaalisilla ehdoilla: kaikki ei ole mahdollista kaikkina aikoina. Tämä ehto ei kuitenkaan sulje teräviä huomioita itse kuvan merkitysrakenteesta.

Useassa yhteydessä Didi-Huberman viittaa myös Aby Warburgin paatosmuodostoihin (Pathosformeln) anakronistisina muotoina ja näkee Warburgin ajatuksen renessanssin kuvien

13 Georges Didi-Huberman, L'immagine insepolta. Aby Warburg, la memoria dei fantasmi e la storia dell'arte (Torino: Bollari Boringhieri, 2006), 83-84.

14 Cesare Segre, La pelle di san Bartolomeo. Discorso e tempo dell'arte (Torino: Giulio Einaudi, 2003), 87.
Nachlebenistä anakronismin voittokulkuna. ${ }^{15} \mathrm{On}$ oikeastaan vaikea ajatella, että tiettyjen paatosmuotojen paluu historian eri kausina olisi anakronismia. Pikemminkin se on muotojen kunkin hetkistä uudelleentulkintaa, jossa suhde omaan aikaan muovaa joka tapauksessa kuvaa ja myös sen paatosmuotoa. Esimerkiksi 1470-luvulta lähtien renessanssin kuvataiteilijat tiesivät tarkkaan suhteensa antiikkiin ja "palauttivat" dionyysiset pakanalliset kuvat uusiokäyttöön kristillisinä kärsimyskuvina, "energeettisinä inversioina" (energetisch invertierte Sinngebung), kuten Aby Warburg toteaa. ${ }^{16}$ Variantissa eli kaksi aikakautta: renessanssin tekemä inversio totteli ajan kristillistä kehystä. Siten kuvien "voima" on myös metafora niiden tietoiselle uusiokäytölle uusissa yhteyksissä. Aiemmat muodot palaavat tietyissä kulttuurin tilanteissa - ja Didi-Hubermanin tapauksessa kurottautuvatkin aina Pollockin teoksiin asti. "Kun aika entinen ei koskaan enää palaa", voimme nojata nykyajan luomiin omiin myytteihin. Tarvitaan siis aina tulkitsija, joka saa maalauksen näyttämään "avoimelta ja disorientoivalta" ja siten itseriittoisen itseymmärteiseltä.

Millaisen diakronia-ajatuksen Didi-Hubermanin anakronismi tarjoaa? Onko kyseessä hetken synkronia, ${ }^{17}$ joka takaa kuville ikuisen elämän ja uusiutuvan voiman? Lienee selvää, että vaikka kuvat sysivät kuvahistoriassa toisiaan ja tuoreutuvat historian myöhemmissä vaiheissa, niiden toinen merkitysvektori on löydettävissä kuvien syntyhetken kulttuurissa. Kun tietyn kuvan pinta vaikuttaa vuosisatojen kuluttua, sen "pinta" ni-

15 Georges Didi-Huberman, Ninfa fluida. Saggio sul panneggio-desiderio (Milano: Ascondita SRL, 2019), 26-27; Didi-Huberman, L'image survivante, 82, 87-88 et passim. Ks. myös viite 13 .

16 Aby Warburg, "Einleitung zum Mnemosyne-Atlas (1929)", in Die Beredsamkeit des Leibes. Zur Körpersprache in der Kunst, bearbeitet von Ilsevill Fliedl \& Christoph Geissmar (Wien: Residenz Verlag, 1992), 172.

17 Diakronia tarkastelee kielijärjestelmän muutoksia, synkronia taas sen ajattomia rakenteita. Ks. Jonathan Culler, Ferdinand de Saussure (Helsinki: Tutkijaliitto, 1994), 39.

\section{TaHiTi 2/2021 $\mathbf{y}$}


menomaan vaikuttaa juuri meille modernismin pintateorioiden kautta. Vaikka usein viitataan kuvan itsensä antamaan informaatioon, ${ }^{18} \mathrm{ku}$ van "suora" tutkiminen kaventaa historiallista horisonttia ja lisää siihen helposti sen, minkä haluamme siinä olevan. Voisi muokata Marc Augén ajatusta "history is on our heels" ("historia on kannoillamme") ja todeta: "historia on aina kuvan kannoilla". 19

Didi-Hubermanin lähestymistavan heikkous on juuri implisiittisessä ajatuksessa, että taidekäsitykset eivät muutu, että voimme maalausta katsomalla ujuttaa oman taidekäsityksemme artefaktiin kaukana historiassa ja siten ikään kuin antaa kuvalle taiteellista voimaa omasta ajastamme käsin. Kuitenkin renessanssin taidekäsitys oli aivan toinen kuin omamme, jopa niin pitkälle, että Giorgio Vasari tarkoitti 1400-luvun lopun primitiivisyydellä, johon hän katsoi Fra Angelicon kuuluvan, aivan eri asiaa kuin romantikot ja myöhemmin modernistiset primitivistit. Aikatasojen sotkeminen taiteellisuuden nimissä tekee taidehistoriasta lopulta iloista mystisismiä.

On tärkeää ja symptomaattista, että Aby Warburg -tutkijat eivät ole lämmenneet Didi-Hubermanin anakronismi-ajatukselle. Christopher Johnsonin esittämät rohkeatkin tulkinnat Warburgin metaforiikasta ja ekspressioteorioista eivät mainitse anakronismin käsitettä. Eivät liioin Claudia Wedepohlin tutkimukset. ${ }^{20}$ Anakronismin

18 Segre, La pelle di san Bartolomeo, 87.

19 Keith Moxey viittaa Augén lausumaan. Ks. Keith Moxey, Visual Time. The Image in History (Durham \& London: Duke University Press, 2013), 41.

20 Ks. Christopher D. Johnson, Memory, Metaphor, and Aby Warburg's Atlas of Images (New York: Cornell University Press, 2012); Claudia Wedepohl, "Pathos - Polarität - Distanz - Denkraum. Eine archivarische Spurensuche," im Warburgs Denkraum. Formen, Motive, Materialen. Trajekte, bearbeitet von Sigrid Weigel \& Karlheinz Barck (München: Wilhelm Fink Verlag, 2014), 46-48. käsitettä, sen mahdollisuuksia ja ongelmia ei myöskään oteta puheeksi "kuvien voimaa" käsittelevässä David Freebergin The Power of Images -teoksessa. $^{21}$

Keith Moxeyn mukaan fenomenologisen taidehistorian ajatus on: visuaalinen artefakti voi aina luoda oman historiansa; nykyisyys täyttää historiallisen muutoksen. ${ }^{22}$ Moxey on todennut Didi-Hubermanin projektista: "Hän väittää, että kuvien fenomenologinen läsnäolo tekee ne kykeneviksi uhmaamaan aikaa". ${ }^{23}$ Jos näin on, jatkaa Moxey, "taiteen historia on silloin anakronistinen hanke". ${ }^{24}$ Moxey ei näytä myöskään hyväksyvän Nicolas Bourriaudin ajatusta nykyhetkestä "epähistoriallisena". ${ }^{25}$ Moxeyn mukaan "se ajatus, että nykyisyys on "ei-ajan" muoto, jokin sellainen, jossa historia ei enää operoi, uhkaa köyhdyttää, ei ainoastaan ajatuksen menneisyyden toiseudesta vaan myös meidän arvostuksemme tai kunnioituksemme kulttuurien välisistä eroista". ${ }^{26} \mathrm{Oli}$ si kuitenkin toivonut, että Moxey olisi ottanut huomioon hermeneuttiset ongelmat anakronismi-kritiikissään. Oikeastaan Didi-Hubermanin anakronismi-käsitys tuo mieleen Walter Benjaminin ajatuksen kuvista ja historiasta: "Historia ei purkaudu kertomuksiksi vaan kuviksi." ${ }^{27}$

On oikeastaan hieman erikoista, että ei DidiHuberman, sen enempää kuin Keith Moxeykaan viittaa hermeneutiikkaan väitellessään anakronismin puolesta tai sitä vastaan. Nykyhetken

David Freedberg, The Power of Images. Studies in the History and Theory of Response (Chicago \& London: The University of Chicago Press, 1991), passim.

Moxey, Visual Time, 44-45.

lbid., 45.

Ibid., 42.

Ibid.

Ibid., 47. Korostus AK.

Ks. Hayden White, Figural Realism. Studies in Mimesis Effect (Baltimore \& London: The John Hopkins University Press, 2000), 66; ks. myös Walter Benjamin, I/luminationen. Ausgewählte Schriften 1 (Frankfurt am Main: Suhrkamp, 1977), 253. ("Über den Begriff der Geschichte" V). 
luomien ennakkokäsitysten kokonaisuutta kutsutaan "hermeneuttiseksi situaatioksi" ${ }^{28}$ Itse asiassa tämä situaatio edellyttää aina vähintään kaksi aikaa, ei yhtä anakronis(tis)ta toivetta tai mittaa. Kun mietimme anakronistista lähestymiskulmaa, nykyhetkisyyttä on todella katsottava hermeneuttisesti. Se tarkoittaa yksinkertaisesti, HansGeorg Gadamerin ajatusta hieman muunnellen: tulkitsija saattaa unohtaa oman situaationsa historiallisuuden, ${ }^{29}$ ja kokee sen läpinäkyväksi. Juuri näin käy Didi-Hubermanin lähestymistavassa. Gadamerin mukaan nykyisyyttämme erottaa menneestä väistämätön kulttuurinen välimatka, jota traditio - myös tutkimustraditio, Wirkungsgeschichte ja siihen liittyvä tulkintojen vaikutushistoria - yrittävät kuroa umpeen. ${ }^{30}$

\section{Taiteen "ajaton essenssi" anakronismina}

Erääksi anakronismin muodoksi - ennen Didi-Hubermanin käsityksiä - voi katsoa taiteen universalismin. Tätä "ajatonta" suuntausta ovat harrastaneet taidekritiikissä voimallisimmin Lionello Venturin jälkeen - Clement Greenberg ja Michael Fried. Heidän teoreettisten otaksumiensa vuoksi nykyhetki alkoi venyä ikuiseksi nykyhetkeksi. He uskoivat, että kuvataide Edouard Manet'n jälkeen - ja etenkin 1950-luvun kuvataide ennen minimalismia - oli viimein löytänyt maalauksen todellisen ajattoman essenssin, sen tosiolemuksen: maalauksen taiteen ajattoman ja muuttumattoman olemuksen" "the timeless and unchanging essence of the art of paintin-

Ks. Heidegger, Sein und Zeit, 232 (§ 45); vrt. HansGeorg Gadamer, Truth and Method (London: Sheed \& Ward, 1989), 268-270.

29 Hans-Georg Gadamer, Hermeneutiikka. Ymmärtäminen tieteissä ja filosofiassa (Tampere: Vastapaino, 2004), 39.

30 Gadamer, Truth and Method, 297-298; vrt. Gadamer, Hermeneutiikka, 37-39. g"). ${ }^{31}$ Ajattomuuden ainekset olivat maalauksen litteä vaikutelma (flatness) ja sen rajaus. Friedin mukaan nämä kaksi ehtoa määrittivät myös sen, mikä on hyvää taidetta. ${ }^{32}$

Maalaustaiteen oli siis määrä huipentua ajattomuuteen näiden kahden normin nojalla. Samalla ne sanelivat sen, miten maalaustaide "kehittyy" kehittämällä vain sen omaa mediumia ja saavuttaa lopulta muuttumattoman, ikuisen essenssin. ${ }^{33}$ Syntyi paradoksi: ajattomuudesta voi puhua vain aikaan ja tarkemmin sanoen taiteellisen kehityksen huippuun viitaten. Friedin sanoin flatness-maalauksissa on kysymys "jatkuvasta ja kokonaisesta tämänhetkisyydestä (presentness)". 34

Kului yllättävän paljon aikaa, kunnes huomattiin, että nämä määritelmät olivat etnosentrisyytensä lisäksi mielivaltaisia, ja että niiden silmämäärä oli amerikkalainen pelkistävä modernismi. Kun ajattomuuden virtaan uppoaa, ei välty paradokseilta. Greenbergin ja Friedin määritelmät omaksuttiin silti eri puolilla maailmaa, vaikka niiden ongelmat olisivat olleet nähtävissä. Josef Kosuthin mukaan ongelmallisuus piili seuraavassa ajatuksessa: miten maalaustaide voi kehittyä, jos jo etukäteen tiedetään, mitä on hyvä ja ajaton maalaustaide. ${ }^{35}$

Kun taiteen edistyvyyttä perusteltiin universalismilla, luotiin samalla paradoksi, jota taiteen itsensä piti selittää. Tällaisen asenteen jäljet johtavat romantiikkaan. 1800-luvun alun prerafaelii-

31 Michael Fried, Art and Objecthood (Chicago \& London: The University of Chicago Press, 1998), 35; vrt. Clement Greenberg, "Towards a Newer Laocoon," in "Pollock and After. The Critical Debate, edited by Francis Francina (London: Harper \& Row, 1985), 35-46, 42.
32

33

34

35 Fried, Art and Objecthood, 39.

Ibid.

Fried, Art and Objecthood, 44-45.

Ks. Josef Kosuth, Art After Philosophy and After. Collected Writings, 1966-1990 (Cambridge, MA \& London: The MIT Press, 1998), 16-18; ks. myös Altti Kuusamo, "Havainto ja kieli, esine ja mieli," teoksessa Synnyt, toim. Timo Valjakka (Helsinki: Nykytaiteen museo, 1989), 235. 
teille ja nasareeneille "rehellisen" taiteellisuuden mallin antoivat 1400-luvun "primitiivit" - taiteilijat, jotka elivät ennen "luonnon jäljittelyn" täydellistymistä eli Rafaelia ja täysrenessanssia. Niinpä 1800-luvun alusta saakka luettiin historiaa toisessa järjestyksessä: ensin Fra Angelico, Piero della Francesca - ja viimein Giotto 1900-luvun vaihteessa ja sen jälkeen. Nämä tarvittiin tässä järjestyksessä, jotta modernismin primitivismi olisi tullut historialla siunatuksi. Useat tyyliperiodit elävätkin kuin huomaamatta kahdessa ajassa: toinen, varhaisempi, tarvitaan nykyisyyden puolustajaksi ja takaajaksi. Aiempi myytti vahvistaa uutta myyttiä. On oikeastaan erikoista, että ajattoman taiteen ajatus vaatii ja vaalii käsitystä primitivismistä - Venturista Didi-Hubermaniin.

Ajan kulku ja siihen kytketty tyylillinen edistyminen tulivat monella tavalla haasteeksi modernismin taiteilijoille. Ajan kulku ja taiteen kehitys yhtäläistettiin. Ne eivät voineet kulkea "takaperin". Diakronian oli oltava yhdensuuntainen, lineaarinen. Kun kehityksen suunta oli valittu, paluuta aiempaan ei ollut. Pikemminkin odotettiin jatkuvaa kehitystä, jossa ei enää saa katsoa "taaksepäin" historiaan. Kuvataiteellisessa modernismissa taaksepäin silmäily katsottiin taiteelliseksi regressioksi tai itsemurhaksi. Paul Mann kommentoi: "Uusi tuli sekä välttämättömyydeksi että fataaliksi laiksi”. ${ }^{36}$ Uuden normatiivisesta tavoittelusta ei sittemmin tullut vanhentunutta, ei ainakaan taidemaailmassa.

Taakseen katsomisen sääntöä on kuitenkin silloin tällöin rikottu. Kasimir Malevitsh ja Francis Picabia, esimerkiksi, päättivät tehdä figuratiivisia teoksia abstraktien jälkeen. Picabian tapaus on sekä kiinnostava että "varoittava" esimerkki. Hänen öljymaalauksensa Femmes au bull-dog (Nainen ja bulldoggi, 1941-42) oli monille shokki, koska se oli kuulaan plastis-realistinen. Timothy van Laar ja Leonard Diepeveen kommentoivat:

36 Paul Mann, A Theory-Death of the Avantgarde (Bloomington: Indiana University Press, 1991), 91.
"Teos pudotti hänet pois planeetan pinnalta". ${ }^{37}$ Figuurimaalaus ei ollut prestiisin mukaista henkilöltä, joka oli tehnyt niinkin pelkistetyn teoksen kuin Danses à la source 1 vuonna 1912.

Giorgio de Chirico puolestaan palasi myöhemmin tekemään teoksia aiemmalla tyylillään, mitä muun muassa André Breton paheksui. De Chiricon voidaan sanoa tapailleen oman synkroniansa ulottuvuuksia, kun hän 1920-luvun puolivälissä sanoi hyvästit lineaariselle modernistiselle aikakäsitykselle ja palasi yhä uudestaan aiempiin metafyysisen kauden teoksiinsa. Uusia maalauksia ei usein erota hänen aiemmista teoksistaan, vaikka hän tekikin niitä ironisesti muunnellen. ${ }^{38} \mathrm{De}$ Chiricoa syytettiin pysähtyneisyydestä, vaikka hän yritti pysäyttää aikaa - ja kenties nopeuttaa myyntiä.

1980-luvun lopussa alkoi lopulta näyttää siltä, että modernismin "nouseva" lineaarisuus ei ollut enää ainoa kriteeri. Julian Spalding toteaakin: " $[\mathrm{M}]$ odernistinen käsitys avantgarden askelaskeleelta -edistymisestä ei ole enää vakuuttavaa tai puolustettavissa." ${ }^{39}$ Näillä lausunnoilla ei kuitenkaan ole ollut paljon merkitystä. Taiteen kentän myyttisyys kosketti usein myös tutkimusta. Voikin sanoa, että ajatus modernistisen taiteen lineaarisuudesta tuotti lopulta anakronismin, mikä on oikeastaan paradoksaalista, koska anakronistinen näkemys juuri vastustaa lineaarista historiakäsitystä. Kysymys oli pikemmin stagnaatiosta, jonka merkit tulivat esiin Friedin ja Greenbergin ajattomuuden ideasta: lineaarinen kehitys johtaa ajattomuuteen. Voimme oikeastaan vain puhua diakronian dialektiikasta: on olemassa diakronia myös väliaikaista synkroniaa varten.

37 Timothy van Laar \& Leonard Diepeveen, Artworld Prestige. Arguing Cultural Value (Oxford: Oxford University Press, 2013), 63.

38 Ks. Altti Kuusamo, "Giorgio de Chirico, melankolia, aika, synestesia. Modernin melankolian dynamiikkaa VIII, 2. osa," Synteesi nro 1-2 (2020): 22, 26-27.

39 Julian Spalding, The Eclipse of Art. Tackling the Crisis in Art Today (Munich, Berlin, London: Prestel, 2003), 94.

\section{TaHiTi 2/2021 $\mathbf{y}$}




\section{Kronotopia: ajan ja paikan yhteenliittymät}

Ennen kuin pohdin heterokronian ulottuvuuksia, on luotava katsaus aika-paikka -relaatioiden eräänlaiseen ensiasteeseen, kysymykseen kronotopiasta. Tämä juuri sen takia, että anakronistiset käsitykset unohtavat paikanmääritykset taiteen historiassa. Käsitteen isä, Mihail Bahtin, tarkoitti kronotopialla alun perin "ajallisten ja paikallisten suhteiden [- -] keskinäistä sidonnaisuutta" ja rajasi sen ensi sijassa kirjallisuuden ilmiöksi, vaikka termi oli lainattu luonnontieteistä. Kronotoopilla on Bahtinin mukaan "kirjallisuudessa lajiominaisuuksia määräävä merkitys". ${ }^{40}$ Laajemmin ottaen tämä tarkoittaa myös kirjallisen perinteen vaikutusta seuraaviin aika-paikka -käsityksiin. Taidehistoriassahan vastaava prosessi jakautuu eri genrien kesken tyylikausipainotteisesti. Kirjallisuudessa kronotopia on erilainen rakenne: se ei ole sidottu tyylikausiin. Henry Miller voi kaikessa rauhassa lainata Francois Rabelais'n kirjoitustyyliä ja modernisti Marcel Proustin kirjallinen tyyli voidaan lopulta nähdä lähempänä 1700-luvun kirjallista tyyliä kuin monen aikalaiskirjailijan.

Ajallisuus ja paikallisuus eksistoi siis kirjallisuudessa eri tavoin kuin kuvataiteessa, jossa kunkin ajan "tyyli" värittää koko kuvien tantereen. Tätä ei useinkaan ymmärretä. Kirjallisuudentutkimus voikin hypellä analyyseissään aikakaudesta toiseen aivan eri tavoin kuin taidehistorian tutkimus ja kuvataiteen käytännöt (ehkä 1980-luvulle saakka). On myös muistettava, että epiikka mahduttaa kokonaisen kielellisen maailman itseensä. Voisi sanoa: jokainen romaani on oma aikakautensa. Mihail Bahtin lausui asian seuraavasti: "Tästä johtuu aivan erilaisten kirjallisuuden ilmiöiden rinnakkaiselo, joka vaikeuttaa tavattomasti historiallista kirjallisuudentutkimusta" ${ }^{41}$ Bahtin

40 Mihail Bahtin, Kirjallisuuden ja estetiikan ongelmia, käänt. Kerttu Kyhälä-Juntunen (Moskova: Progress, 1979), 243-244.

41 Ibid tarkoittaa tässä sitä, että kirjallisuuden historia voi panna eri aikakaudet samalle janalle kielen ilmaisujen suhteen.

Yhtä kaikki, voimme kronotopialla kuvataiteessa tarkoittaa sitä, miten paikka ja aika ovat suhteessa toisiinsa kuvissa: maalaukset ja arkkitehtuuri syntyvät tiettyyn paikkaan tai kuvaavat tiettyjä paikkoja - ja ovat tietyn paikkakulttuurin synnyttämiä. Silloin kun aika-paikka -relaatiot eri kulttuurien kosketuksessa sekoittuvat, olemme oikeastaan hyvin lähellä sitä, mitä nykyään yhä useammin kutsutaan heterokroniaksi.

Paikka voi myös herättää tietyn aikakauden ja muuttaa näkemyksiä nykyhetkestä. Tästä on paljon huonoja ja hyviä esimerkkejä. Huonoja ns. Siena-ilmiön suhteen. 1950-luvulla modernit arkkitehdit vaelsivat Italiaan, Sienaan, ihailemaan piazza del Campoa. He ajattelivat, että sen hienous voidaan muuttaa "suhteiksi" ja palasivat takaisin suunnittelemaan lisää valkoisia ikkunanauhalaatikoita ja teräs- ja lasikoteloita, jotka eivät ollenkaan näyttäneet sellaiselta kuin piazza del Campon näkymät, eivätkä juuri poikenneet arkkitehtien edellisistä suunnitelmista. "Suhteet" eivät luoneetkaan samanlaista vaikutelmaa. ${ }^{42}$

Myönteisemmin ymmärrettynä aika-paikka -relaatio huomioi historian. Arkkitehti Louis Kahnille oleskelu Roomassa merkitsi suurta muutosta hänen arkkitehtuurinäkemyksissään. Historian resonanssi oli mahdollista nykyisyydessä. Filosofi ja esteetikko Arthur Danto kirjoittaa, miten ratkaiseva tämä Roomassa vietetty aika oli Kahnin lisäksi myös hänelle itselleen. Siellä hän löysi taidehistorioitsija Rudolf Wittkowerin tekstit. Oleskelustaan Roomassa Danto toteaa: "Näin kaiken historiallisen muuntuvuuden (transfiguration) merkeissä. [- -] En koskaan sen jälkeen voinut olla sinut formalismin kans-

Ks. Altti Kuusamo, "Muoto, merkitys, muisti," Synteesi nro 3 (1988): 97-98; vrt. myös Robert Venturi, Complexity and Contradiction in Architecture (New York: The Museum of Modern Art Press, 1984), 62. Olen edelleen kehitellyt Venturin ideoita mainitussa tekstissäni, luvussa "Piazza del Campo -syndrooma".

\section{TaHiTi 2/2021 $\mathbf{y}$}


sa”, hän kommentoi. ${ }^{43}$ Voidaankin sanoa, että Rooman kronotopia muutti Danton näkemykset aikakausisuhteista perustavanlaatuisesti. Mutta kronotopia merkitsee tässä myös herätettä huomaamaan historiallisen heterokronian olemassaolo: Rooma oli eri paikka ja aika 1600-luvulla kuin Danton ja Kahnin aikana.

\section{Heterokronia vaihtoehtona?}

Pamela Lee on esitellyt käsitteen kronofobia, aikakauhu, kuvatakseen sen avulla 1960-luvun erikoista suhdetta aikaan. Tuolloin elettiin kulttuurin tihenevien rytmien paradigmaattista aikakautta ja käytiin siten sotaa ajan kulumista vastaan. Samalla aika haluttiin kohottaa absoluuttiseksi mittariksi kaikelle nopealle muutokselle. Yhden aikaperiodin sisään täytyi saada mahdutetuksi paljon enemmän kuin aiemmin. Hyvä esimerkki tästä on On Kawaran Date paintings, joihin taiteilija taltioi kunkin päivän päivämäärän. Siten ajankohta itsessään tuli kuvan aiheeksi ja sisällöksi. ${ }^{44}$ Ajan ja tapahtumisen rytmi oli kiihkeää ja sen takia pienikin aikaväli täyttyi tiheästä tapahtumisesta. Ajan ongelma olikin käsitetaiteelle keskeinen haaste. Pamela Lee toteaa: "Voisimme kirjoittaa teostolkulla käsitetaiteen sitoutumisesta aikakysymyksiin: se on itsessään loputon päähänpinttymä” ${ }^{45}$ Leen kommentti tuo mieleen Gillo Dorflesin ajatuksen aikaintervallien kutistumisesta nykykulttuurin eri alueilla. ${ }^{46}$

1960-luku on hyvä esimerkki myös siitä, miten kulttuurin eri alueiden suhteet tiivistyivät. Siten

43 Arthur Danto, Philosophizing Art. Selected Essays (Berkeley: University of California Press, 1999), 195.

44 Pamela Lee, Chronophobia. On Time in the Art of the 1960s (Cambridge, MA \& London: The MIT Press, 2004), 8, 293-297. Ajankohdan nostamisesta teoksen aiheeksi, ks. Roberta Smith, "Conceptual Art," teoksessa Concepts of Modern Art, ed. Nikos Stangos (London: Thames and Hudson), 267.

45 Ibid., 288

46 Gillo Dorfles, L'intervallo perduto (Milano: Skira, 2006), 3-9, 22-27. voimmekin huoletta puhua 1960-luvun hengestä. Esimerkkejä on riittämiin. Olen toisaalla analysoinut 1960 -luvun suhdeverkkoa. ${ }^{47}$ Pierre Bourdieun toiminta 1960-luvulla osoittaa hyvin, miten Zeitgeist-ajattelu ottaa mallia jonkin aikaisemman periodin Zeitgeist-ajattelusta perustellakseen olemassa olevia tiiviitä eri alueiden yhteyksiä. Bourdieu toimi koko 1960-luvun läheisessä yhteistyösuhteessa kuvataiteilija Bernard Rancillaciin. ${ }^{48}$ Tämä yhteistyö eri alojen välillä tuli myös perustelluksi sillä, että Bourdieu käänsi Erwin Panofskyn teoksen Gothic Architecture and Scholasticism ranskaksi. Teos käsittelee samankaltaisuuksia 1200-luvun alun arkkitehtuurin ja skolastiikan välillä: systemaattinen älyllinen toiminta johtaa supra-persoonallisiin "tapojamuovaaviin-voimakenttiin". ${ }^{49}$

Kaikkein hätkähdyttävin todistus syvästä muutoksesta on Umberto Econ toiminta: "Kun sitten tuli 60-luku, se yhtäkkiä kaatoi päälleen ajan tasalla pysymisen kastikkeen ja hukutti lapsensa siihen [- -] Löydöt muuttuivat kiihtymykseksi, kiihtymys lingvistiseksi tottumukseksi, lingvistinen tottumus hermoväreeksi, hermoväreet kohtuuttomuudeksi”. ${ }^{50}$ Näin voi käydä silloin, kun heterogeenisimmillakin älyllisillä toiminnoilla on homogeeninen ajallinen yhteys.

1960-luku synnytti paradoksin: aika piti pysäyttää kulttuurin nuortumisen nimissä nopeuttamalla taiteen muutoksia. Syntyi myös toinen paradoksi: diakronia (ajallisten muutosten ulottuvuus) etsi synkronista momenttiaan taiteen jatkuvan muutoksen nimissä. Diakronia näytti muuttuvan synkroniaksi, kun muutoksesta tuli stagnaatio.

47 Ks. Altti Kuusamo, "Identiteetistä toiseen: 60-luku," teoksessa Mediatieteen kysymyksiä 2, toim. Sam Inkinen, Eva Sundgren, Mauri Ylä-Kotola (Rovaniemi: Lapin yliopisto, 1998), 323-350.

48 Sarah Wilson, The Visual World of French Theory: Figurations (New Haven \& London: Yale University Press, 2010), 64-97.

49 Ibid., 79; vrt. Erwin Panofsky, Gothic Architecture and Scholasticism (New York: Meridian, 1976), 36-45.

50 Umberto Eco, Matka arkipäivän epätodellisuuteen (Helsinki: WSOY, 1984), 190. 
Usein on mietitty, kumpi Louis Ferdinand de Saussuren keksimistä merkityksen sivuista on pitempi, diakronia vai synkronia? Diakronia merkitsee muuttuvaa ja siten epäjatkuvaa ajanmääritystä, kun taas synkronia merkitsee muuttumattomien rakenteiden ja merkitysten ulottuvuutta. Siten kielellä on synkroninen rooli, sen kielioppi luo historiaan pysyvyyden syvyyssuunnan: ymmärtäisimme ilman Lönnrothin Kalevalaa Agricolan ajan kieltä. Diakronia liittyy ajallisesti muuttuviin kielioppeihin, joista paras esimerkki on kuvataiteen tyyliperiodit. Jokainen periodi haluaa luoda oman kielensä, vaikka se tuntuisi vain kielen pinnalta. Diakronian "laidalle" sijoittuvat sellaiset kuvataiteen suuntaukset, jotka ovat jokseenkin immuuneja suurille aikakausimuutoksille - tai eivät välitä niistä. ${ }^{51}$ Tällöin tyyli muuttuu lajiksi, kuten kävi naivismin muuntuessa "toritaiteeksi". Tyylistä tulee laji - ja lajista lopulta esteettinen painolasti.

Modernismille oli aivan keskeinen se Ernst Jüngerin ajatus, että moderniteettiin kuului taipumus vaeltaa "kevyellä pakkauksella" (mit leichtem Gepäck). Modernismi jätti taakseen kaiken raskaan: mimesiksen taiteessa, traditionaalisen mestaruuden, perityt eettiset ja esteettiset konventiot ja antiikin mytologisen tradition ylläpitämisen. Taide, musiikki ja filosofia hylkäsivät kaiken liiallisen painon ja pyrkivät radikaaleihin reduktioihin. ${ }^{52}$ Tämä voittoisa reduktionismi saavutti lakipisteensä - ei niinkään romaanitaiteessa - vaan juuri 1950-luvun yhä pelkistyvässä abstraktismissa, jossa se pysytteli koko 1960-luvun ja lopulta johti taiteen immaterialisointiin käsitetaiteen nimissä - ja lopuksi sen vastakohtaan, toimintataiteeseen. Tämä "kevytpakkaus" vaati ainoastaan yhden mausteen: uuden mytologisoinnin. Tähän uuden mytologisointiin liittyi myös ajatus periodin täydellisestä erilaisuudesta aiempaan nähden, ikään

51 Ks. Altti Kuusamo, Tyylistä tapaan - semiotiikka, tyyli, ikografia, (Helsinki: Gaudeamus, 1996), 198-199.

52 Boris Groys, Going Public (Berlin: Sternberg Press, 2010), 86-87. kuin mytologisoinnin takaajana. Samalla tähän kevytpakkaukseen oli sisällytetty kaikki tulevat anakronismit.

Peter Koselleck toteaa, että juuri moderniteetti teki ajasta itsestään dynaamisen ja historiallisen voiman tavalla, joka oli uusi (sic!) "historian kollektiivinen singulaari" ${ }^{53}$ Kuten usein on todettu, moderniteetti ei ainoastaan asettunut antiikkia ja keskiaikaa vastaan, vaan yleensä koko traditiota vastaan. ${ }^{54}$ Paul Ricoeur sanoo sen näin: "Tosiasiassa moderniteetti on yhtä aikaa sekä itseään arvostava että itseensä viittaava. Se karakterisoi itsensä ylivertaiseksi epookiksi määrittämällä itsensä laadultaan tämänhetkisyydeksi." ${ }^{55}$ Voi sanoa, että Friedrich Schlegelin "uuden poeettisen mytologian" ohjelma, joka romantiikan alkuvaiheessa pyrki tekemään täydellisen eron "vanhan ajan" symbolisiin käytäntöihin, ${ }^{56}$ oli ensimmäinen askel tämän "uuden" laadullistamiseksi.

Diakroniaan kuuluva tyylimurros on Slavoj Žižekin mukaan aina tapahtuma (event) $.^{57} \mathrm{Fi}-$ losofi Maurice Blanchot puolestaan toteaa: jos myönnät sen tosiasian, että olet käännekohdassa, tosiasiallisesti et ole käännekohdassa. ${ }^{58}$ Käännekohta tuntuu määrittävän meitä enemmän kuin me käännekohtaa. Oikeastaan ei ole erikoista vaan tyypillistä se, että jokainen vuosi nykyisessä hektisessä ajassamme tuntuu käännekohdalta. Aikatietoisuuteemme herkkyys luo tämän illuusion.

Peter Koselleck, Futures Past. On the Semantics of Historical Time (Cambridge, MA: The MIT Press, 1985), 246,249 .

54 Ks. esim. Peter Osborne, The Politics of Time. Modernity and Avan-Garde (London: Verso, 1995), 14.

55 Paul Ricoeur, Memory, History, Forgetting (Chicago \& London: The University of Chicago Press, 2006), 310.

56 Ks. Friedrich Schlegel, Über literatur, Kunst und Geist des Zeitalters (Stuttgart: Reclam, 1964), 104.

57 Slavoj Žižek, Event (London, Penguin Books, 2014), 180-181.

58 Žižek, Event, 179.

\section{TaHiTi 2/2021 $\mathbf{Y}$}


Jos on niin, että kronofobia on lisääntynyt tyylien saostumisen jälkeen - ja synnyttänyt mielikuvan siitä, että aiemman diakronian esimerkit elävät synkronisesti samassa ajassa, se merkitsee myös uutta haastetta heterokronialle - sille, että monet aika- ja paikkatasot ovat yhtä aikaa sekä miellettävissä että käytettävissä, konteksteja unohtamatta. A. Nagelin ja C. Woodin esittämä ajatus pluraalista temporaalisuudesta on nähdäkseni lähellä heterokronian käsitettä. ${ }^{59}$

Aiempi länsimainen aikakäsitys ja ajatus "kehityksestä" ulotettiin koskemaan myös kolonisoituja maita - ja siten hallitsemaan kaikkea kulttuurista toiseutta ja vaihtoehtoisia temporaalisuuksia, heterokroniaa. Vallalla oleva taiteen aikasysteemi olikin asettunut toimimaan kolonialismin aikakaudella. ${ }^{60}$ Länsimaisen kulttuurin aikakäsitys oli, ja edelleen on, universalisoidun taiteen suhteen "ajatonta" taidetta vain tiettyjen aikakausien suhteen. Tällaista käsitystä hallitsi, voisi sanoa, historiallinen kronotopia, historiallinen aika-paikka -käsitys, jonka keskipisteinä ja kriteereinä ovat olleet suuret länsieurooppalaiset maat, pääasiassa Italia ja Ranska.

Kun kasvettiin ajatukseen, että meidän kulttuurimme kronologia on universaalia, taidehistorian länsimaiselle aikajanalle siirrettiin myös meksikolainen, aasialainen ja Lähi-Idän taide. Voisikin sanoa, että varhainen modernismi, tässä tapauksessa prekubismi, pakotti Länsi-Afrikan varhaiskantaiset naamiot meidän kulttuurimme aikajanalle.

Varsin tuore esimerkki siitä, miten meidän kulttuurimme kronologia on yhä ratkaisevassa asemassa, on Julian Bellin kirjoittama tuore taidehistoria Mirror of the World. A New History of the Art (2007). Siinä muiden kulttuurien taidetta tarkastellaan länsimaisen samanaikaisuuden valossa - ikään kuin "kulttuurien välisen vertailun"

59 Nagel \& Wood, Anachronic Renaissance, 7.

60 Vrt. Moxey, Visual Time, 8, 173-174. kautta. ${ }^{61}$ Nykyisin on kuitenkin selvää, että eri kulttuurien aikakäsitykset ja "aikajanat" ovat hyvin erilaisia. Niiden kronotopia on toinen ja siten myös heterokronia - eli eriaikaisuus.

Tutkimustapaamme luonnehtii kuitenkin edelleen voittopuolisesti se, että kaikki uusi voi kumota entiset käsitykset vain päivämäärän perusteella. Tutkimusasetelmat muuttuvat nopeasti: Jacques Lacanista ollaan yhtäkkiä hiljaa avantgarde-tutkimuksen piirissä, mutta Iranissa hänen ajattelunsa saa osakseen yhä enemmän opiskelijoiden mielenkiintoa.

Tutkimuskohdetta ja -asenteen eroja on vaikea huomata silloin, kun on kysymys toisaalla olevan kulttuurin taiteesta. Heterokronia merkitseekin: meidän on otettava huomioon eri kulttuurien omat aikavyöhykkeet. ${ }^{62}$ On kuitenkin myös niitä, jotka näkevät, että juuri nykytaide elää ajattomuudessa ja että heterokronia tapahtuu meidän taiteessamme. Näin ajattelee esimerkiksi Nicolas Bourriaud. ${ }^{63}$ Ajatus heterokronian mahdollisuudesta on kuitenkin vaarassa: globalisaation myötä taidekulttuuri on homogenisoitunut ja ottanut yhä enemmän ilmiöitä valkoisen kuutionsa sisään. Tämän prosessin varjopuoliin havahtuminen ei kuitenkaan pysäytä taidekauppaa, jonka keskus on postkolonialistinen Lontoo. Samalla kun se sulattaa taideilmiöitä samalle huutokauppapöydälle, tutkijoille on tullut tarve nähdä aikakaudet, ei pelkästään ajallisessa syvyyssuunnassa vaan myös kulttuurien eripaikkaisuuden mukaan. Tällä tavalla aikamme subjektiivinen ja relatiivinen, Henri Bergsonista alkunsa saanut aikakäsityksen malli voidaan valjastaa laajempiin tarkoituksiin ja siten avata mahdollisuus tarkastella kulttuurisen toiseuden aikakäsityksiä yliyksilöllisinä ilmiöinä. Tähän paradoksiin on toistaiseksi tyytyminen.

61 Julian Bell, Mirror of the World. A New History of the Art (London: Thames and Hudson, 2007), 7.

62 Keith Moxey, Visual Time, 43.

63 Nicolas Bourriaud, The Exform (London: Verso, 2015), 47,60 .

\section{TaHiTi 2/2021 $\mathbf{y}$}


Anakronismin ongelma on juuri historiallisen toiseuden saostuminen. Anakronisti ei esimerkiksi osaa vastata kysymykseen, miksi Hagar ja enkeli -aihe ilmestyi maalaustaiteeseen juuri 1600-luvun alussa? ${ }^{64}$ Asian selvittäminen vaatii aikakauden ainutkertaisten psykohistoriallisten ja uskonnollisten muutosten sekä muiden kontekstien tutkimista ja ymmärtämistä. Tämä tutkiminen ei kuitenkaan poissulje sitä, että huomaamme ennen huomaamattomia piirteitä eri Hagar ja enkeli -maalauksissa. Aiemmin ei esimerkiksi ole kiinnitetty huomiota siihen, että enkeli koskettaa Hagaria. ${ }^{65}$ Tämä on siis aikamme huomio, joka saattaa yhdistää tutkijaa aikamme vallitseviin tutkimusintresseihin. Kuitenkin tuon ajan katoliseen uskoon liittyvät visuaaliset yksityiskohdat saattavat vain tuoda julki kulttuurisen kuilun aikamme ja 1600-luvun välillä.
Tässä mielessä heterokronian käsite on soveliaampi korostamaan eri kulttuurien ja eri aikakausien ajallista toiseutta ja erilaisuutta. Heterokroonikko ottaa huomioon muutosten hermeneuttiset kytkökset ja myöntää aikakausien väistämättömän kulttuurisen erilaisuuden. Kun anakronisti haluaa unohtaa oman tutkimusajankohtansa historiallisuuden jonkin hetkellisesti vireillä olevan taiteen trendin nojalla, hän samalla unohtaa juuri laajasti opitun kontekstuaalisen toiseuden käsitteen. Loppuyhteenveto on tässä mielessä helppo kiteyttää: heterokroninen asenne pyrkii ottamaan huomioon kontekstit ja kulttuurisen erilaisuuden, kun taas anakronistinen asenne haluaa formalistisesti unohtaa ne taideteoksen historiattoman olemistavan nimissä. Anakronismi on näin ollen vain uusi formalismin muoto.

\begin{abstract}
Altti Kuusamo on taidehistorian emeritusprofessori (Turun yliopisto), Helsingin yliopiston taidehistorian dosentti ja Lapin yliopiston mediasemiotiikan dosentti. Hänen kiinnostuksen kohteisiinsa lukeutuvat post-renessanssi, taidehistorian metodologia sekä nykytaide teorioineen.
\end{abstract}

\section{Lähteet}

Bahtin, Mihail. Kirjallisuuden ja estetiikan ongelmia. Suom. Kerttu Kyhälä-Juntunen. Moskova: Progress, 1979.

Bal, Mieke. Quoting Caravaggio. Contemporary Art, Preposterous History. Chicago \& London: The University of Chicago Press, 1999.

Bell, Julian. Mirror of the World. A New History of the Art. London: Thames and Hudson, 2007. 
Benjamin, Walter. Illuminationen. Ausgewählte Schriften 1. Frankfurt am Main: Suhrkamp, 1977.

Bourriaud, Nicholas. The Exform. Trans. by Erik Butler. London: Verso, 2015.

Culler, Jonathan. Ferdinand de Saussure. Suom. Risto Heiskala. Helsinki: Tutkijaliitto, 1994.

Danto, Arthur. Philosophizing Art. Selected Essays. Berkeley: University of California Press, 1999.

Didi-Huberman, Georges. L'image survivante, Histoire de l'art et temps des fantomes selon Aby Warburg. Paris: Les Éditions de Minuit, 2002.

Didi-Huberman, Georges. "Before the image, Before Time: The Sovereignty of Anachronism." In Compelling Visuality, edited by Claire Farago \& Robert Zwijnenberg, 31-44. Minneapolis \& London: University of Minnesota Press, 2003.

Didi-Huberman, Georges. L'immagine insepolta. Aby Warburg, la memoria dei fantasmi e la storia dell'arte. Torino: Bollari Boringhieri, 2006.

Didi-Huberman, Georges. Ninfa fluida. Saggio sul panneggio-desiderio. Tradotto da R. Rizzo. Milano: Ascondita SRL, 2019.

Dorfles, Gillo. L'intervallo perduto. Milano: Skira, 2006.

Eco, Umberto. Matka arkipäivän epätodellisuuteen. Suom. A. Buffa. Helsinki: WSOY, 1984.

Fried, Michael. Art and Objecthood. Chicago \& London: The University of Chicago Press, 1998.

Freedberg, David. The Power of Images. Studies in the History and Theory of Response. Chicago \& London: The University of Chicago Press, 1991.

Gadamer, Hans-Georg. Truth and Method. Second, revised edition. Trans. by J. Weinsheimer \& D. Marshall. London: Sheed \& Ward, 1989.

Gadamer, Hans-Georg. Hermeneutiikka. Ymmärtäminen tieteissä ja filosofiassa. Käänt. I. Nikander. Tampere: Vastapaino, 2004.

Greenberg, Clement. "Towards a Newer Laocoon." In Pollock and After. The Critical Debate, edited by Francis Francina, 35-46. London: Harper \& Row, 1985.

Groys, Boris. Going Public. Berlin: Sternberg Press, 2010.

Heidegger, Martin. Sein und, Zeit. Tübingen: Max Niemayer Verlag, 1993.

Johnson, Christopher. Memory, Metaphor, and Aby Warburg's Atlas of Images. New York: Cornell University Press, 2012.

Koselleck, Peter. Futures Past. On the Semantics of Historical Time. Trans. by K. Tribe. Cambridge, MA: The MIT Press, 1985.

Kosuth, Joseph. Art After Philosophy and After. Collected Writings, 1966-1990. Cambridge, MA \& London: The MIT Press, 1998.

Kubler, George. The Shape of time. Remarks on the History of Things. New Haven \& London: Yale University Press, 1962.

Kuusamo, Altti. "Muoto, merkitys, muisti." Synteesi 7, nro 3 (1988): 84-110.

Kuusamo, Altti. "Havainto ja kieli, esine ja mieli." Teoksessa Synnyt, toim. Timo Valjakka, 227-248. Helsinki: Nykytaiteen museo, 1989.

Kuusamo, Altti. Tyylistä tapaan: semiotiikka, tyyli, ikonografia. Helsinki: Gaudeamus, 1996.

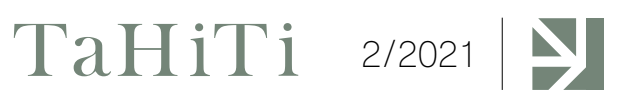


Kuusamo, Altti. "Identiteetistä toiseen: 60-luku." Teoksessa Mediatieteen kysymyksiä 2, toimittaneet Sam Inkinen, Eva Sundgren, Mauri Ylä-Kotola, 323-349. Rovaniemi: Lapin yliopisto, 1998.

Kuusamo, Altti. "Michelangelo ja melankolian vieteri." Synteesi 25, nro 4 (2006): 19-41.

Kuusamo, Altti. "Giorgio de Chirico, melankolia, aika synestesia. Modernin melankolian dynamiikkaa VIII, 2. osa." Synteesi 39, nro. 1-2 (2020): 13-39.

Laar, Timothy van \& Diepeveen, Leonard. Artworld Prestige. Arguing Cultural Value. Oxford: Oxford University Press, 2013.

Lee, Pamela. Chronophobia. On Time in the Art of the 1960s. Cambridge \& London: The MIT Press, 2004.

Mann, Paul. A Theory-Death of the Avantgarde. Bloomington: Indiana University Press, 1991.

Moxey, Keith. Visual Time. The Image in History. Durham and London: Duke University Press, 2013.

Nagel, Alexander \& Wood, Christopher. Anachronic Renaissance. New York: Zone Books, 2010.

Osborne, Peter. The Politics of Time. Modernity and Avan-Garde. London: Verso, 1995.

Paul Ricoeur. Memory, History, Forgetting. Trans. by Kathleen Blamet \& David Pellaur. Chicago \& London: The University of Chicago Press, 2006.

Saxl. Fritz. A Heritage of Images. Harmondsworth: Penguin Books, 1970.

Schlegel, Friedrich. Über literatur, Kunst und Geist des Zeitalters. Stuttgart: Reclam, 1964.

Segre, Cesare. La pelle di san Bartolomeo. Discorso e tempo dell'arte. Torino: Giulio Einaudi, 2003.

Spalding, Julian. The Eclipse of Art. Tackling the Crisis in Art Today. Munich, Berlin, London: Prestel, 2003.

Venturi, Robert. Complexity and Contradiction in Architecture. New York: The Museum of Modern Art Press, 1984.

Warburg, Aby. "Einleitung zum Mnemosyne-Atlas (1929)." Im Die Beredsamkeit des Leibes. Zur Körpersprache in der Kunst, bearbeitet von Ilsevill Fliedl \& Christoph Geissmar, 171-173. Wien: Residenz Verlag, 1992.

Wedepohl, Claudia. "Pathos - Polarität - Distanz - Denkraum. Eine archivarische Spurensuche." Im Warburgs Denkraum. Formen, Motive, Materialen, bearbeitet von Sigrid Weigel \& Karlheinz Barck, 17-49. München: Wilhelm Fink Verlag, 2014.

White, Hayden. Figural Realism. Studies in Mimesis Effect. Baltimore \& London: The John Hopkins University Press, 2000.

Wilson, Sarah. The Visual World of French Theory: Figurations. New Haven \& London: Yale University Press, 2010.

Žižek, Slavoj. Event. London: Penguin Books, 2014. 